\title{
自尊感情の高さおよび変動性と 他者からの評価に対する恐れとの関連
}

\author{
○澤口 友祐 ${ }^{1}$ 堀内 聡 $^{2}$ \\ (1岩手県立大学大学院社会福祉学研究科 $\cdot 2$ 岩手県立大学) \\ キーワード : 自尊感情; 他者からの否定的な評価に対する恐れ; 他者からの肯定的な評価に対する恐れ
}

\begin{abstract}
Relationship between height and variability of self-esteem and fear of evaluation from others
Yusuke SAWAGUCHI ${ }^{1}$, Satoshi HORIUCHI ${ }^{2, \#}$

( ${ }^{1}$ Graduate School of Social Welfare, Iwate Prefectural Univ., ${ }^{2}$ Iwate Prefectural Univ)
\end{abstract}

Key Words: Self-esteem; Fear of negative evaluation (FNE); Fear of positive evaluation (FPE)

\section{目 的}

自尊感情は自己に対する肯定的な評価と定義されている

(Baumeister, 1998)。他方, 自尊感情の変動性は, 短期間にお ける自尊感情の変動のしやすさ（阿部・今野・松井, 2008）と 定義されている。

FNE は「否定的な評価への苦痛，他者から否定的に評価さ れるという予測」である。FPE は「公の場で好ましく評価さ れることにまつわる恐怖」のことを指す（前田・関口・堀内・ Weeks ・ 坂野, 2015)。

阿部他（2008）は，自尊感情の高さおよび変動性と他者に 対する不安との関連を検討し, 自尊感情の高さのみが他者に 対する不安の低さと関連することを示した。この他者に対す る不安はFNE および FPE を含む広範な概念である。しかし， 自尊感情の高さおよび変動性とFNEおよびFPEとの関連を検 討した研究はない。また, 自尊感情の変動性が自尊感情の高 さと対人的不適応との関係を修飾するという知見（阿部他, 2008）から, 自尊感情の変動性が, 自尊感情の高さと FNE お よびFPEの関係を修飾する可能性がある。

本研究では, 自尊感情の高さおよび変動性と FNE および FPE との関連について検討することを目的とする。

\section{方 法}

\section{参加者}

参加者 94 名のうち, 未回収や欠損を除いた 78 名（男性 14 名, 女性 64 名, 平均年齢 20.22 歳）を分析対象者とした。

\section{調査項目}

自尊感情の高さと変動性の測定には, 状態自尊感情尺度 (阿 部・今野, 2007）を用いた。これは 9 項目で構成されている。 調査票を配布した後, 同一参加者に 1 日 1 回, メールで回答 を依頼し 7 日間測定した。そして, その平均值を高さの指標, 標準偏差を変動性の指標とした。それぞれの得点が高いほど 自尊感情の高さ, 自尊感情の変動性が高いことを示す。

FNE の測定には Fear of Negative Evaluation Scale 日本語短縮 版（笹川他, 2004）を用いた。全 12 項目のうち, 高い妥当性 が確認されている順項目の 8 項目を用いた（荒井他, 2015）。 合計得点が高いほど FNEの值が高いことを示す。

FPE の測定には Fear of Positive Evaluation Scale 日本語版 （前田他, 2015）を用いた。これは10 項目で構成されている。 合計得点が高いほど FPEの值が高いことを示す。

\section{結 果と考察}

FNE，FPE を従属変数として，それぞれ自尊感情（高さ高 群・高さ低群）と変動性（変動性高群・変動性低群）を独立 变数とする 2 要因分散分析を行った(Table1)。FNEにおいて, 有意な自尊感情の高さの主効果のみが認められ, 自尊感情の
高さ高群は高さ低群よりも FNE が低くなっていた $(F(1,77)=$ $4.75, p<.05)$ 。他方, FPEにおいて, 有意な自尊感情の高さの 主効果のみが認められ, 自尊感情の高さ高群は高さ低群より も FPE が低くなっていた $(F(1,77)=4.86, p<.05)$ 。

本研究の結果, 自尊感情の高さは否定的, 肯定的に関わら ず他者からの評価に対する恐れの低さと関連することが明ら かになった。他方，自尊感情の変動性は，FNE および FPEに 直接的に影響せず, 高さと FNE および FPE の関連を修飾する 要因でもないことが明らかになった。

Table1

他者からの否定的な評価に対する恐れ，他者からの肯定的な 評価に対する恐れを従属変数, 自尊感情の高さおよび変動性 を独立変数とした 2 要因分散分析

\begin{tabular}{|c|c|c|c|c|c|c|c|}
\hline \multirow{2}{*}{$\begin{array}{c}\text { 自尊感情の高さ } \\
\text { 自尊感情の変動性 }\end{array}$} & \multicolumn{2}{|c|}{ 高高群 } & \multicolumn{2}{|c|}{ 高学低群 } & \multicolumn{2}{|c|}{ 主効果 } & \\
\hline & 変動性高群 & 校動此低群 & 変動州高 & 変動性低群 & 自尊感掅の & 尊感清の & 交互作用 \\
\hline $\begin{array}{l}\text { 他者からの否定的な } \\
\text { 評価に刘才万恐九 }\end{array}$ & $\begin{array}{l}25.91 \\
(8.76)\end{array}$ & $\begin{array}{r}24.87 \\
(7.13)\end{array}$ & $\begin{array}{l}30.22 \\
(2.71)\end{array}$ & $\begin{array}{l}27.04 \\
(5.79)\end{array}$ & $4.75^{*}$ & 2.01 & 0.52 \\
\hline $\begin{array}{l}\text { 他者加らの肯定的な } \\
\text { 評佃に刘す恐れ }\end{array}$ & $\begin{array}{l}18.82 \\
(8.34)\end{array}$ & $\begin{array}{l}22.67 \\
(9.86)\end{array}$ & $\begin{array}{c}27.78 \\
(15.00)\end{array}$ & $\begin{array}{c}25.92 \\
(11.54)\end{array}$ & $4.86 *$ & 0.13 & 1.06 \\
\hline
\end{tabular}

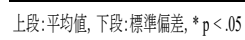

\section{引用文献}

阿部 美帆・今野 裕之 (2007). 状態自尊感情尺度の開発 パ ーソナリティ研究, 16,36-46.

阿部 美帆・今野 裕之・松井豊 (2008). 日誌法を用いた自 尊感情の変動性と心理的不適応との関連の検討 筑波大 学心理学研究, 35, 7-15.

荒井 穂菜美・青木 俊太郎・前田 香 -二瓶 正登・岩野 卓 . 富岡 奈津代・堀内 聡 - 坂野雄二 (2015). Fear of Negative Evaluation Scale 日本語短縮版の妥当性の検討 日本うつ病学会総会 日本認知療法学会プログラム抄録 集, $12,15,290-290$.

Baumeister, R. F. (1998). The self. In D. T. Gilbert, S. T. Fiske, \& G. Lindzey (Eds.), The handbook of social psychology. 4th ed. Vol. 1. New York: McGraw-Hill.

前田 香 - 関口 真有 - 堀内 聡 - Justin W. Weeks ・ 坂野 雄二 (2015). Fear of Positive Evaluation Scale 日本語版の信頼 性と妥当性の検討 不安症研究, 6, 133-120.

笹川智子 - 金井 嘉宏 - 村中 泰子 - 鈴木 伸一 - 嶋田 洋徳 坂野 雄二 (2004). 他者からの否定的評価に対する社会 的不安測定尺度 (FNE)短縮版作成の試み一一項目反応理 論による検討—— 行動療法研究, 30, 87-98. 